\title{
"How Can We Act?" A Praxiographical Program for The Rhetoric of Technology, Science, and Medicine
}

\author{
Carl G. Herndl \\ Department of English, University of South Florida \\ Tampa, FL USA
}

\section{Lauren Cutlip}

Department of English, University of South Florida

Tampa, FL USA

Poroi 9,1 (April 2013)

The history of scholarship in the humanities in the twentieth century is to a considerable degree a response to changing institutional, social and intellectual conditions. The literary new criticism was influenced by the aversion to politics during the cold war, the need to professionalize literary studies with a unique object and disciplinary nomenclature, and the pressure to teach a huge influx of G.I.'s who lacked the careful training in Latin, Greek and the great books necessary for Germanic philology. Closer to home, composition developed a disciplinary apparatus and theory in response to the inauguration of open admissions that produced work like Mina Shaughnessy's (1977) Errors and Expectations. Closer still, the field of technical and professional communication, at least in English, was a response to the growing requirements for engineers to take technical writing courses, the emergence of ethnography as a research method for understanding nonacademic writing, and the reemergence of classical rhetoric in English departments at places like Rensselaer Polytechnic Institute. Other than Mathes and Stevenson's (1976) Designing Technical Reports, there were no textbooks available for the new technical writing courses that began to appear in the late 1970s and early 1980 . To the extent that the rhetoric of science is a "mission-oriented" project rather than a "curiosity-oriented" project, to borrow a distinction from history of science, I think our future will similarly be a response to a finite set of intellectual and material contingencies. ${ }^{1}$

\section{What Is Happening to the Rhetoric of Science?}

In his wonderful introduction to Rhetoric and Incommensurability, Randy Harris (2005) answers the historical question of what happened in

\footnotetext{
${ }^{1}$ This paper is written in the first person singular because the first half of the paper where the disciplinary position is articulated is largely Herndl's work, while the second half of the paper is largely Cutlip's work.
} 
the mid- to late twentieth century to create the field of the rhetoric of science with a single word: Kuhn. An overstatement perhaps, but a powerful one. I'm tempted to imitate Harris and say simply: Latour. But who wants to be that derivative? And I might just as easily say "uncertainty," or "climate change," or "sustainability," or "science studies," or even "budget cuts." I want to say that, like that of any disciplinary project, the future of the rhetoric of science will be guided by an internal logic of theory and an external logic of material opportunities and demands. But I'm uncomfortable with that distinction. The field is a hybrid of these motive forces, neither of which excludes the other.

To be schematic, I think the rhetoric of science (ROS) or the rhetoric of technology, science, and medicine (RTSM) is shifting from a modern and humanist disciplinary focus to a non-modern and post-human focus. This shift includes a change in our dominant theory of realism, our understanding of agency, and the location where we do our work. To illustrate this shift, let me compare Charles Bazerman's (1988) chapter "Making Reference" from Shaping Written Knowledge to Bruno Latour's (1999) "Circulating Reference" from Pandora's Hope.

\section{Bazerman's "Making Reference"}

Bazerman examines Arthur Holly Compton's texts and focuses on the "developed system of scientific communication" (p. 191). The institutional "haggling over experience" generates arguments over the best way to represent experience and how to hold representations "accountable to the experience" (p. 190). The core resource for the scientist is the "communal structure" that constrains and enables scientific behavior and communication (p. 191). Bazerman is carefully agnostic about issues of truth and never says "true" or "truth"; his notion of "accountable" is an openly pragmatist position in which the consequences and results of the account determine its power and efficacy.

In these respects, Bazerman is very similar to Latour. Both texts avoid postmodern critiques of reference and examine scientific practice to construct a realistic, almost pragmatist account of reference. Both examine scientific process and activity. Both seek a way out of postmodern discourse critique. Both want a more practical theory of realism. But Bazerman's argument depends on metaphors of "contact," of being "accountable," of "precise exchange," "close concourse," "constant relation," and "close relation," all of these "shot through with empirical experience" (p. 192), "freighted with empirical experience" to "adjust constantly that representation to experience" (p. 195). This characterization is uncannily close to what Latour does and says, but the metaphorical system is grounded in a theory of perspective and metaphors of seeing and representation, all the core theoretical issues in the 1980s. The enabling agent here is "the communal structure" (p. 191), "the institutions of scientific communication" (p. 191), and the "developed system of scientific communication" (p. 191). The final claim is that this system "helps scientists behave like scientists and do good science" (p. 191). This carefully hedged sentence avoids truth claims and the correspondence theory of truth but also avoids overt social construction ("helps"), and it defines "good science" as "precise exchange with 
phenomenon" through which "symbols of language come into contact with the world" (p. 188).

These analytic metaphors echo Kuhn's (1962) discussion in Structure of Scientific Revolutions where he talks of how scientists "attach" a law to nature and where he describes the experience of solving exemplar problems as allowing scientists to adopt a "group-licensed way of seeing" (p. 189, italics added). Both Kuhn and Bazerman warrant their realism and metaphors by referring to Ludwig Fleck's The Genesis and Development of a Scientific Fact (1979) in which nature "constrains" scientific statements. And all these critics depend on Kant's argument in Critique of Pure Reason that the forms of sensible intuition determine the shape reality takes for man. For Kant, Fleck, and Bazerman, the world is outside, separated and, to quote Latour, "contributes decisively but minimally" (p. 6). This project is fundamentally epistemological, and it is driven by questions of representation and accuracy. And it is this problematic that produces the vague and unsatisfying metaphors in Bazerman's text. Lest you hear me criticize Bazerman's text too harshly, I think his work is the very best that can be done within the modern, humanist conception of science.

\section{Latour's "Circulating Reference"}

Where Bazerman reads Compton's texts, Latour goes out into the Brazilian jungle as a member of a field expedition and meticulously records in ethnographic style the doings of the scientific team of which he is a member. For Latour and others who use ethnographic methods to study the doing of science, practice makes opaque what tradition makes transparent. Latour's goal is not critique, but understanding; he accepts the reality of science, and he produces a theory of reference that rejects the impassable gap between word and world, signifier and signified, in favor of an uninterrupted chain of tiny transformations that trace the movement from Amazonian dirt to a scientific graph in a journal article. He describes how reference brings back into discourse the material reality of the world that finally makes science legitimate.

The essence of Latour's theory is that reference is a "non-saltatory movement," to borrow William James' term (1907/1975), underwritten by an uninterrupted chain of very small transformations rather like an evidentiary chain of custody in the law. In place of metaphors of "constraint" and communal "ways of seeing," Latour adopts non-modern metaphors of translation, quasi-objects and quasi-subjects, propositions and concretization, drawn from William James, A. N. Whitehead, and Michel Serres. These metaphors allow Latour to articulate a theory in which humans and nonhumans are equally actants in the making of reality and the constitution of a realist theory of reference. Latour's posthuman and distributed theory of agency is part of a renewed materialism that explores the effectivity or agency of objects, Latour's nonhumans (Bennett, 2010; Coole \& Frost, 2010), and the political implications of this shift (Braun \& Whatmore, 2010). Collectively, this is an ontological and essentially pragmatist project. 


\section{A Move Toward Praxiography}

Annemarie Mol (2002) characterizes this as "shifting from understanding objects as the focus point of various perspectives to following them as they are enacted in a variety of practices [and] impl[ying] a shift from asking how sciences represent to asking how they intervene" (p. 152). The "praxiography" Mol describes moves us away from incommensurability and the briar patch of epistemological issues invoked by Latour's "brainin-a-vat" or what Richard Bernstein (1983) calls our collective "Cartesian anxiety" about certainty, to questions of post-plurality and multiple ontologies. This moves us from a focus on saying and representing to a concern for doing and intervening, from "how do we know?" to "how can we act?"

Much of Latour's recent work is motivated by what he calls the impending "ecocide" and the pressing need for adequate environmental policy. Books like Reassembling the Social (2007) and The Politics of Nature (2004a) are driven by Latour's concern about the public controversy over climate change and the ineffectiveness of climate policy initiatives. And this problem will have an equally powerful influence on RTSM. To a considerable degree, however, the future of our discipline will also be a response to more mundane pressures: the increasing reconfiguration of universities in which funding is increasingly STEM; the interdisciplinary collaboration that is increasingly necessary for research funding; the influence of grant funding on tenure and promotion decisions even in the humanities. RTSM will flourish as a participant in interdisciplinary research projects in which rhetoric functions as a significant contributor to research, outreach, and policy formation.

To flourish in this new institutional environment, however, rhetoricians need to turn the kinds of non-modern ideas Latour and company articulate into practical strategies for helping manage the uncertainty of post-normal science and policy formation. This shift from analysis of science and its discourse to collaborating in the management of uncertainty is the move Latour (2004) calls for in "Why Has Critique Run Out of Steam," where he redefines the critic as one who brings things together in matters of concern. It is what Collins and Evans (2002) call for in their conception of the third wave of science studies, where humanities and science studies scholars work "upstream" of technology development, or what Herbert Simons (2005) calls "reconstructive rhetoric" (p. 239). And it addresses the problem Marlia Banning (2009) identifies so nicely when she describes how the critique of postmodern theory has been co-opted by the political right to fight climate change policy.

\section{Four Research Foci}

At the risk of considerable self-aggrandizement, I will illustrate this possibility by describing the proposal my colleagues Kalanithy Vairavamoorthy, Ali Yalcin, and I recently finished to create a new Patel College of Global Sustainability at University of South Florida (USF). This interdisciplinary college will be without departments, organized by problem-driven work teams who identify central issues in sustainability, 
largely in urban areas of the developing world. We spent much of the last six months designing this new college and writing the final proposal that went to the USF faculty senate for approval on November 14, 2013. This college will include an Institute for Applied Rhetoric of Science and Sustainability that will have both its own independent research agenda and be partnered with the central research initiatives of the college. As I devote my efforts to building this new college, I realize that I am laying my academic bets on a vision of the future of our field. Guided by what I have said to this point, I will design the Institute for Applied Rhetoric of Science and Sustainability with four research foci: science policy, citizen participation, modeling, and data visualization.

\section{Science Policy}

For mission-oriented science, influencing the formation of sound public policy that brings government, citizens, and scientists together is the holy grail. Especially in sustainability studies, scientists and engineers know that good science is not enough. Addressing the challenges of the emerging ecocide requires careful policy. The research in this area reflects an understanding that bridging this gap between science and policy is a rhetorical issue. The question at hand is how to take the information produced by scientists and use it to get things done. How do we communicate science, and with whom should we communicate, in order to mobilize policy? The central questions of this issue include:

1. Why is there a gap between science and policy? (Cash, Borck, \& Patt, 2006; Jasanoff, 1987; Lindenfeld, Hall, McGreavy, Silka, \& Hart, 2012; McNie, 2007; Peterson, Peterson, \& Peterson, 2005).

2. What is the role of the scientist? (Elzinga, 2012; Gibbons, 1999; Ozawa \& Susskind, 1985).

3. How do organizational boundaries impact policy formation? (Guston, 1999, 2001).

4. How is science policy a specifically rhetorical issue? (Cox, 2010; Foust \& Murphy, 2009; Lakoff, 2010; Nisbet, 2009; Zittoun, 2011).

5. How can we explain uncertainty to the public to influence support for policy? (Fischhoff, 2007; Weber \& Stern, 2011).

\section{Citizen Participation}

As Fiorino argued in 1990, including citizens in technology development and decision-making creates better technology, increases public adoption of new technologies, and supports basic democratic principles against a technocratic model of science and technology. A widely read watershed article on citizen participation by Collins and Evans (2002) articulates a normative theory of "non-credentialed" experts and their participation in technology development. Some of the crucial questions concerning citizen participation include: 
1. Is public participation useful? Why is public participation necessary? (Herian, 2011; Laird, 1993; Webler, 1995).

2. What is public participation? What does or should it look like? (Abelson, Forest, Eyles, Smith, Martin, \& Gauvin, 2003; Fiorino, 1990; Lengwiler, 2008; Roberts, 2004; Rowe \& Frewer, 2005).

3. How do we evaluate participation mechanisms? (Burton, 2009; Carr \& Halvorsen, 2001; Rowe \& Frewer, 2000; Rowe, Marsh, \& Frewer, 2004; Rothstein, 2007).

4. Is public participation effective? (Bogner, 2012; Cotton \& DevineWright, 2012; Nielsen, Lassen, \& Sandøe, 2011; Wilkinson, Bultitude, \& Dawson, 2011).

5. How do communication and talk affect participation? (Blythe, Grabill, \& Riley, 2008; Grabill \& Simmons, 1998; Veen, Molder, Gremmen, \& van Woerkum, 2012).

6. How do we understand and evaluate expertise? (Allgaier, 2011; Boyd, 1998; Clark, Wegener, Habashi, \& Evans, 2012; Collins \& Evans, 2002; Collins \& Weinel, 2011; Fischer, 1993; Goodwin, 2011; Majdik \& Keith, 2011; Munnichs, 2004; Su, 2012).

\section{Modeling}

Post-normal science concerning complex, non-linear systems such as climate change, agroecosystem management, or ocean systems that cannot be controlled or easily studied in laboratories or in experimental conditions depends on models that take advantage of the enormous capacities of supercomputers. This shift represents a major change in how science operates in the twenty-first century, and it entails complex rhetorical problems and affordances. Some of the central questions regarding this issue include:

1. How and how effectively does modeling represent uncertainty? (Buede, Mahoney, Ezell, \& Lathrop, 2012; Cobb \& Thompson, 2012; Sriver, Urban, Roman, \& Keller, 2012).

2. How can modeling bridge the science-policy divide and aid in decision-making? (Gabbert, van Ittersum, Kroeze, Stalpers, Ewert, \& Olsson, 2010).

3. How do models shape research and practice? (Huber \& Kutschenko, 2009).

4. How can we incorporate rhetoric/affective behavior prediction into modeling? (Lodder, 2004; Nyborg, 2003).

\section{Data Visualization}

As Ortiz (2007, p. 231) argued:

current visualization technologies [are] especially relevant to our understanding of globalization and the global system. If by visualization we mean 'a method for seeing the unobservable,' then information visualization has yet to acquire the status of mainstream methodology within the social sciences (Orford et al., 
1999, p. 300). As yet, visualization has not enjoyed a strong, central, and coordinated research program to put forth visualization in mainstream scholarship - other than geography scholarship with a slow diffusion process often taking place from the 'harder sciences' to the 'softer sciences' (Orford et al., 1999, p. 300).

Visualization, however, is a significant strategy in connecting science, policy and citizens. Some of the emerging questions involved with this issue include:

1. What are the tools for analyzing and visualizing networks? (Shi, Zhou, Wu, \& Liu, 2009).

2. What is the role of user interaction in visualization technologies? (Liang \& Sedig, 2010; Simorov, Otte, Kopietz, \& Oleynikov, 2012).

3. How can we teach non-experts to use visualization technologies? (Freyne \& Smyth, 2010; Heer, Van Ham, Carpendale, Weaver, \& Isenberg, 2008).

4. How can visualization technologies transfer knowledge across fields, to non-experts, and contribute to decision making? (Huang, Chen, Yip, Ng, Guo, Chen, \& Roco, 2003; Pham, Streit, \& Brown, 2009; Wuqi \& Jifa, 2009; Zhu \& Chen, 2008).

\section{Conclusion}

As useful as our tradition of scholarship in the rhetoric of science has been in establishing the field, it will change substantially as it responds to the demands and opportunities of this new landscape. RTSM will thrive if it builds interdisciplinary alliances, engages with our colleagues in science to help manage uncertainty and the threat of ecocide, and develops specific strategies and tools to put into practice our disciplinary intentions to make a difference. We should move from talking about science to doing science.

\section{References}

Abelson, J., Forest, P. G., Eyles, J., Smith, P., Martin, E., \& Gauvin, F. P. (2003). Deliberations about deliberative methods: Issues in the design and evaluation of public participation processes. Social Science \& Medicine, 57(2), 239-251.

Allgaier, J. (2011). The difficulty of differentiating expertise and the functions of expert sources and the necessity of studying science education in the media. Humanities, Social Sciences, and Law, 6(2), 479-484.

Banning, M. (2009). When poststructural theory and contemporary politics collide: The vexed case of global warming. Communication and Critical/Cultural Studies, 6(3), 285-304.

Bazerman, C. (1988). Making reference: Empirical contexts, choices, and constraints in the literary creation of the Compton effect. In Shaping written knowledge: The genre and activity of the experimental 
article in science (pp. 187-234). Madison, WI: University of Wisconsin Press.

Bennett, J. (2010). Vibrant matter: A political ecology of things. Durham, NC: Duke University Press.

Bernstein, R. (1983). Beyond objectivism and relativism. Philadelphia, PA: University of Pennsylvania Press.

Blythe, S., Grabill, J. T., \& Riley, K. (2008). Action research and wicked environmental problems: Exploring appropriate roles for researchers in professional communication. Journal of Business and Technical Communication, 22(3), 272-298.

Bogner, A. (2012). The paradox of participation experiments. Science, Technology, \& Human Values, 37(5), 506-527.

Boyd, G. (1998). Pastoral conversation: A postmodern view of expertise. Pastoral Psychology, 46(5), 307-321.

Braun, B., \& Whatmore, S. J. (2010). Political matter: Technoscience, democracy, and public life. Minneapolis, $\mathrm{MN}$ : University of Minnesota Press.

Buede, D., Mahoney, S., Ezell, B., \& Lathrop, J. (2012). Using plural modeling for predicting decisions made by adaptive adversaries. Reliability Engineering \& System Safety, 108, 77-89.

Burton, P. (2009). Conceptual, theoretical and practical issues in measuring the benefits of public participation. Evaluation, 15(3), 263284 .

Carr, D. S., \& Halvorsen, K. (2001). An evaluation of three democratic, community-based approaches to citizen participation: Surveys, conversations with community groups, and community dinners. Society and Natural Resources, 14(2), 107-26.

Cash, D., Borck, J., \& Patt, A. (2006). Countering the loading-dock approach to linking science and decision-making: Comparative analysis of El Nino/Southern Oscillation (ENSO) forecasting systems. Science, Technology, \& Human Values, 31(4), 465-494.

Clark, J., Wegener, D., Habashi, M., \& Evans, A. (2012). Source expertise and persuasion: The effects of perceived opposition or support on message scrutiny. Personality and Social Psychology Bulletin, 38(1), 90-100.

Cobb, A., \& Thompson, J. (2012). Climate change scenario planning: A model for the integration of science and management in environmental decision-making. Environmental Modelling and Software, 38, 296-305.

Collins, H. M., \& Evans, R. (2002). The third wave of science studies: Studies of expertise and experience. Social Study of Science, 32(2), 235-296.

Collins, H. M., \& Weinel, M. (2011). Transmuted expertise: How technical non-experts can assess experts and expertise. Argumentation, 25(3), 401-413. 
Coole, D. H. and Frost, S. (Eds.). (2010). New materialisms: Ontology, agency, and politics. Durham, NC: Duke University Press.

Cotton, M., \& Devine-Wright, P. (2012). Making electricity networks "visible": Industry actor representations of "publics" and public engagement in infrastructure planning. Public Understanding of Science, 21(1), 17-35.

Cox, R. (2010). Beyond frames: Recovering the strategic in climate change communication. Environmental Communication, 4(1), 122-133.

Elzinga, A. (2012). Features of the current science policy regime: Viewed in historical perspective. Science and Public Policy, 39(4), 416-428.

Fiorino, D. J. (1990). Citizen participation and environmental risk: A survey of institutional mechanisms. Science, Technology, \& Human Values, 15(2), 226-243.

Fischer, F. (1993). Citizen participation and the democratization of policy expertise: From theoretical inquiry to practical cases. Policy Sciences, 26(3), 165-187.

Fischhoff, B. (2007). Non-persuasive communication about matters of greatest urgency: Climate change. Environmental Science \& Technology, 41, 7204-7208.

Fleck, L. (1979). The genesis and development of a scientific fact. Chicago, IL: University of Chicago Press.

Foust, C., \& Murphy, W. (2009). Revealing and reframing apocalyptic tragedy in global warming discourse. Environmental Communication, $3(2), 151-167$.

Freyne, J., \& Smyth, B. (2010). Visualization for the masses: Learning from the experts. Lecture Notes in Computer Science, 6176, 111-125.

Gabbert, S., van Ittersum, M., Kroeze, C., Stalpers, S., Ewert, F., \& Olsson, J.A. (2010). Uncertainty analysis in integrated assessment: The user's perspective. Regional Environmental Change, 1O(2), 131-142.

Gibbons, M. (1999). Science's new social contract with society. Nature, 40 2(6761S), C81-C84.

Goodwin, J. (2011). Accounting for the appeal to the authority of experts. Argumentation, 25(3), 285-296.

Grabill, J.T., \& Simmons, M. (1998). Toward a critical rhetoric of risk communication: Producing citizens and the role of technical communicators. Technical Communication Quarterly, 7(4), 415-441.

Guston, D. H. (1999). Stabilizing the boundary between politics and science: The role of the Office of Technology Transfer as a boundary organization. Social Studies of Science, 29(1), 87-112.

----. (2001). Boundary organizations in environmental policy and science: An introduction. Science, Technology, \& Human Values, 26(4), 399408.

Harris, R. A. (2005). Introduction. In R. A. Harris (Ed.), Rhetoric and incommensurability (pp. 3-121). West Lafayette, IN: Parlor Press. 
Heer, J., Van Ham, F., Carpendale, S., Weaver, C., \& Isenberg, P. (2008). Creation and collaboration: Engaging new audiences for information visualization. Lecture Notes in Computer Science, 4950, 92-133.

Herian, M. (2011). Local budgeting and public participation: Contextual predictors of state laws mandating public input. State and Local Government Review, 43(2), 95-109.

Huang, Z., Chen H., Yip A., Ng, G., Guo F., Chen, Z.-K., \& Roco, M.C. (2003). Longitudinal patent analysis for nanoscale science and engineering: Country, institution and technology field. Journal of Nanoparticle Research, 5(3-4), 333-363.

Huber, L., \& Kutschenko, L. (2009). Medicine in a neurocentric world: About the explanatory power of neuroscientific models in medical research and practice. Medicine Studies, 1(4), 307-313.

James, W. (1975/1907) Pragmatism and the meaning of truth. Cambridge, MA: Harvard University Press.

Jasanoff, S. (1987). Contested boundaries in policy-relevant science. Social Studies of Science, 17(2), 195-230.

Kant, I. (1998). Critique of pure reason (P. Guyer \& A.W. Wood, Trans.). New York: Cambridge University Press.

Kuhn, T. S. (1962). The structure of scientific revolutions. Chicago, IL: University of Chicago Press.

Laird, F. N. (1993). Participatory analysis, democracy, and technological decision-making. Science, Technology, \& Human Values, 18(3), 34161.

Lakoff, G. (2010). Why it matters how we frame the environment. Environmental Communication, 4(1), 70-81.

Latour, B. (1999). Circulating reference. In Pandora's hope: Essays on the reality of science studies (pp. 24-79). Cambridge, MA: Harvard University Press.

----. (2004a). The politics of nature: How to bring the sciences into nature. Cambridge, MA: Harvard University Press.

----. (2004b). Why has critique run out of steam? Critical Inquiry, 30, $225-48$.

----. (2007). Reassembling the social: An introduction to actor-network theory. Oxford, England: Oxford University Press.

Lengwiler, M. (2008). Participatory approaches in science and technology: Historical origins and current practices in critical perspective. Science, Technology, \& Human Values, 33(2), 186-200.

Liang, H., \& Sedig, K. (2010). Role of interaction in enhancing the epistemic utility of $3 \mathrm{D}$ mathematical visualizations. International Journal of Computers for Mathematical Learning, 15(3), 191-224.

Lindenfeld, L., Hall, D., McGreavy, B., Silka, L., and Hart, D. (2012). Creating a place for environmental communication research in sustainability science. Environmental Communication, 6(1), 23-43. 
Lodder, A. (2004). Law, logic, rhetoric: A procedural model of legal argumentation. Logic, Epistemology, and the Unity of Science, 1(V), 569-588.

Majdik, Z., \& Keith, W. (2011). Expertise as argument: Authority, democracy, and problem-solving. Argumentation, 25(3), 371-384.

Mathes, J. C., \& Stevenson, D. W. (1976). Designing technical reports: Writing for audiences in organizations. Indianapolis, IN: BobbsMerrill.

McNie, E. C. (2007). Reconciling the supply of scientific information with user demands: An analysis of the problem and review of the literature. Environmental Science \& Policy, 1O(1), 17-38.

McGreavy, D., Silka, B., \& Hart, D. (2012). Creating a place for environmental communication research in sustainability science. Environmental Communication, 6(1), 23-43.

Mol, A. (2002). The body multiple: Ontology in medical practice. Durham, NC: Duke University Press.

Munnichs, G. (2004). Whom to trust? Public concerns, late modern risks, and expert trustworthiness. Journal of Agricultural and Environmental Ethics, 17(2), 113-130.

Nielsen, A. P., Lassen, J., \& Sandøe, P. (2011). Public participation: Democratic ideal or pragmatic tool? The cases of GM foods and functional foods. Public Understanding of Science, 2O(2), 163-178.

Nisbet, M. C. (2009). Communicating climate change: Why frames matter for public engagement. Environment, 51(2), 12-23.

Nyborg, K. (2003). The impact of public policy on social and moral norms: Some examples. Journal of Consumer Policy, 26(3), 259-277.

Orford, S., Harris, R., \& Dorling, D. (1999) Geography: Information visualization in social sciences. Social Science Computer Review, 17(3), 289-304.

Ortiz, C. (2007). Visualization: Exploring growth and development in the global system. In N. Choucri et al. (Eds.), Mapping sustainability: Knowledge e-networking and the value chain (pp. 231-260). Alliance for Global Sustainability Bookseries, London, UK: Springer.

Ozawa, C., \& Susskind, L. (1985). Mediating science-intensive policy disputes. Journal of Policy Analysis and Management, 5(1), 23-39.

Peterson, M. N., Peterson, M. J., \& Peterson, T. R. (2005). Conservation and the myth of consensus. Conservation Biology, 19(3), 762-767.

Pham, B., Streit, A., \& Brown, R. (2009). Visualization of information uncertainty: Progress and challenges. Advanced Information and Knowledge Processing, 2, 19-48.

Roberts, N. (2004). Public deliberation in an age of direct citizen participation. The American Review of Public Administration, 34(4), 315-353.

Rothstein, H. (2007). Talking shops or talking turkey? Institutionalizing 
consumer representation in risk regulation. Science, Technology, \& Human Values, 32(5), 582-607.

Rowe, G., \& Frewer, L. J. (2000). Public participation methods: A framework for evaluation. Science, Technology, \& Human Values, 25(1), 3-29.

----. (2005). A typology of public engagement mechanisms. Science, Technology, \& Human Values, 3o(2), 251-290.

Rowe, G., Marsh, R., \& Frewer, L. J. (2004). Evaluation of a deliberative conference using validated criteria. Science, Technology, \& Human Values, 29(1), 88-121.

Shaughnessy, M. (1977). Errors and expectations. New York: Oxford University Press.

Shi, C., Zhou, D., Wu, B., \& Liu, J. (2009). VisNetMiner: An integration tool for visualization and analysis of networks. Lecture Notes in Computer Science, 5678, 611-618.

Simons, H. (2005). The rhetoric of philosophical incommensurability. In R. A. Harris (Ed.), Rhetoric and incommensurability (pp. 238-268). West Lafayette, IN: Parlor Press.

Simorov, A., Otte, R. S., Kopietz, C. M., \& Oleynikov, D. (2012). Review of surgical robotics user interface: What is the best way to control robotic surgery? Surgical Endoscopy, 26(8), 2117-2125.

Sriver, R., Urban, N., Roman, O., \& Keller, K. (2012). Toward a physically plausible upper bound of sea-level rise projections. Climatic Change, 115(3-4), 893-902.

$\mathrm{Su}, \mathrm{C}$. (2012). Who knows who knows what in the group? The effects of communication network centralities, use of digital knowledge repositories, and work remoteness on organizational members' accuracy in expertise recognition. Communication Research, 39(5), 614-640.

Veen, M., Molder, H., Gremmen, B., \& van Woerkum, C. (2012). Competing agendas in upstream engagement meetings between celiac disease experts and patients. Science Communication, 34(4), 460-486.

Weber, E. U. and Stern, P. C. (2011). Public understanding of climate change in the United States. American Pyschologist, 66(4), 315-328.

Webler, T. (1995). "Right" discourse in citizen participation: An evaluative yardstick. In O. Renn, T. Webler, \& P. Wiedemann (Eds.), Fairness and competence in citizen participation: Evaluating models for environmental discourse (pp. 35-86). Dordrecht, the Netherlands: Kluwer Academic.

Wilkinson, C., Bultitude, K., \& Dawson, E. (2011). "Oh yes, robots! People like robots; the robot people should do something”: Perspectives and prospects in public engagement with robotics. Science Communication, 33(3), 367-397.

Wuqi, S., \& Jifa, G. (2009). Application of information visualization technologies in masters' experience mining. Communications in 
Computer and Information Science, 35(5), 198-201.

Zhu, B., \& Chen, H. (2008). Information visualization for decision support. In F. Burstein \& C. Holsapple (Eds.), Handbook on decision support systems (pp. 699-722). International Handbook on Information Systems Series. London, UK: Springer.

Zittoun, P. (2011). From instrument to policy: Observing the meaning process to make a decision. Croatian Political Science Review, 48(5), 106-124. 